\title{
Kalkınmada Güney Kore Örneği (The Case of South Korea in Development)
}

\section{Banu ERKÖK IDa $_{\text {a }}$}

a Türk Eximbank, Saray Mah. Ahmet Tevfik İleri Cad. No:19 34768 Ümraniye / İstanbul, Türkiye. berkok@gmail.com

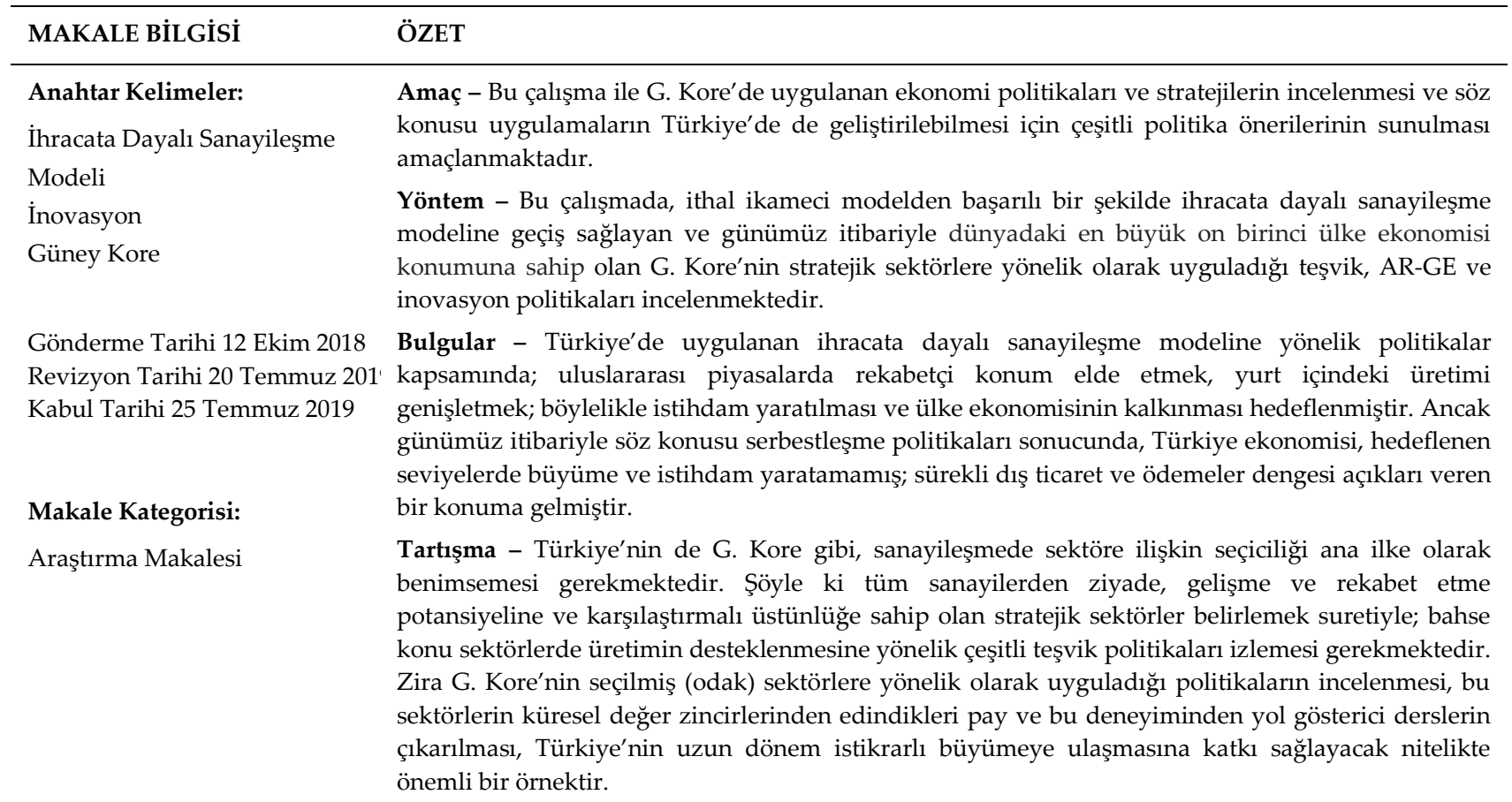

\begin{tabular}{|c|c|}
\hline ARTICLE INFO & ABSTRACT \\
\hline Keywords: & $\begin{array}{l}\text { Purpose - The purpose of this paper is to analyze the economic policies implemented for the } \\
\text { strategic sectors in S. Korea, which is a significant case for Turkey in achieving a stable growth path. }\end{array}$ \\
\hline $\begin{array}{l}\text { Industrialization Model } \\
\text { Innovation } \\
\text { South Korea }\end{array}$ & $\begin{array}{l}\text { Design/ Methodology/ Approach - Within the paper, the specific policies implemented by S. Korea, } \\
\text { who have chosen strategic sectors and applied R \& D or other incentive policies to those sectors and } \\
\text { transformed from the export- led industrialization model to the import-substitution model } \\
\text { successfully and finally became the largest eleventh economy in the world, are analyzed. }\end{array}$ \\
\hline $\begin{array}{l}\text { Received } 12 \text { September } 2018 \\
\text { Revised } 20 \text { July } 2019 \\
\text { Accepted } 25 \text { July } 2019\end{array}$ & $\begin{array}{l}\text { Findings - Within the liberalization policies, Turkey has targeted to increase production, job } \\
\text { creation, economic growth and achieve competitive position in international markets and finally } \\
\text { locate at higher level in global value chains. However, as a result those policies implemented, } \\
\text { Turkey's economy neither could be able to create growth nor employment at the targeted level. } \\
\text { Furthermore Turkey's economy has become a position that has continuous foreign trade and } \\
\text { balance of payments deficits. }\end{array}$ \\
\hline Research Article & $\begin{array}{l}\text { Discussion - As S. Korea, Turkey has to select some strategic sectors for industrialization and adopt } \\
\text { incentive policies for specifically those sectors. That is to say, by identifying strategic sectors that } \\
\text { have the potential for development and competitiveness and comparative advantage, rather than all } \\
\text { industries; Turkey should follow various incentive policies to support production in those sectors. } \\
\text { Taking into account the economic policies implemented for the strategic sectors, S. Korea is a } \\
\text { significant case for Turkey in achieving a stable growth path. }\end{array}$ \\
\hline
\end{tabular}

\section{Giriş}

İhracata dayalı sanayileşme modeli, temelde serbest ticareti simgeleyen bir yaklaşım olup, kalkınma yolundaki ülkelerin serbest ticaret koşullarında karşılaştırmalı üstünlüğe sahip oldukları sektörlerde üretim yapılmasını öngörmektedir. Bu amaçla model çerçevesinde ekonomiyi uluslararası ticarete entegre eden politikaların izlenmesi ve ulusal kaynak tahsisinin, uluslararası talep tarafından belirlenmesine olanak sağlanması öngörülmektedir. Bu bağlamda üretimin, uluslararası düzeyde rekabetçi olması gerekmektedir. 
Modelin dayanağını, serbest ticarete dayanan karşılaştırmalı üstünlükler kuramı oluşturmaktadır. İhracata dayalı sanayileşme modeli kaynak dağılımında, karşılaştırmalı üstünlüklere dayanan uluslararası işbölümünü esas almaktadır. Bu doğrultuda, her ülkenin karşılaştırmalı üstünlügünün bulunduğu alanda uzmanlaşması öngörülmektedir. Böylece uluslararası ticaret serbestçe yapılırsa, dünya ölçeğinde kaynaklar optimal kullanılmış olacak ve bütün ülkeler kazançlı çıkacaktır. İhracata dayalı sanayileşme modelinde, geliştirilmesi öngörülen sanayilerin, iç piyasadan çok dış piyasa için üretim yapmaları amaçlanmaktadır. Model çerçevesinde ülkeler, serbest ticaret koşullarında, karşılaştırmalı üstünlüğe sahip oldukları sektörlerde üretim yapmaya yönelmektedirler. Bir başka ifadeyle, gelişmekte olan ülkeler, tüm sektörlerden ziyade, yalnızca gelişme potansiyeline sahip olan sektörlerde üretimi özendirmeye yönelik politikalar benimsemişlerdir. Karşılaştırmalı üstünlükler teorisi, gelişmekte olan ülkelerin, dış piyasalarda rekabet edebilmek için, görece zengin oldukları kaynaklara dayalı sektörlere ilişkin üretime ağırlık vermesini öngörmektedir. Sanayileşmede sektöre ilişkin "seçicilik" ana ilke olup tüm sanayiden ziyade, gelişme ve rekabet etme potansiyeline sahip olan "odak" sektörlerde üretimin özendirilmesi ve desteklenmesi amaçlanmaktadır. Gelişmekte olan ülkelerin dış piyasalarda rekabet edebilmeleri için seçilen sektörlerdeki üretim tesislerinin, optimum teknik kapasite ile kurulması ve böylelikle, ölçek ekonomilerinden (economies of scale) yararlanması amaçlanmaktadır. "Odak sektör" kavramı ile politika yapıcılar tarafından- G. Kore'de olduğu gibi- ülkenin faktör donanımı ve karşılaştırmalı üstünlükleri göz önünde bulundurularak, ekonominin büyümesinde lokomotif görevi üstlenecek sektörler kastedilmektedir. Bahse konu odak sektörler Hirshman (1958) ve Rasmussen (1957) tarafından anahtar sektör (key sector) olarak tanımlanmaktadır. Hirshman ve Rasmussen'e göre odak sektörler, ileri ve geri bağlantı etkileri yüksek olup ekonominin lokomotifi olan sektörler olarak tanımlanmaktadır. Bir diğer ifadeyle, söz konusu sektörler, ekonomi üzerinde en fazla etkiye sahip olan ve böylelikle büyümeyi diğer sektörler üzerine yayarak tüm sektörlere en fazla etkide bulunan sektörler olarak tanımlanmaktadır. Hirschman (1958) bir ülke ekonomisindeki odak sektörleri belirleyip, bu sektörler lehine teşvikler yaratarak, ekonomiyi bu sektörler öncülüğ̈̈nde desteklemek suretiyle büyümenin önemine vurgu yapmaktadır.

$\mathrm{Bu}$ doğrultuda çalışmada ihracata dayalı sanayileşme modeline ilişkin tanım ve teorik bilgilere yer verilmekte; ithal ikameci modelden başarılı bir şekilde ihracata dayalı sanayileşme modeline geçiş sağlayan ve günümüz itibariyle dünyadaki en büyük on birinci ülke ekonomisi konumuna sahip olan G. Kore'de uygulanan ekonomi politikaları incelenmektedir. Zira 1960 yılında Türkiye'de kişi başına düşen milli gelir düzeyi, G. Kore'dekinin üç katından fazla iken; 2000 ve 2017 yıllarında G. Kore'de kişi başına düşen milli gelir, Türkiye'dekinin neredeyse iki katı düzeyine yükselmiştir. G. Kore, 2017 yılı itibariyle, 26 bin doların üzerinde olan kişi başına düşen gelir düzeyiyle birçok gelişmiş ülkeyi de geride bırakmaktadır. Söz konusu ülkenin 2015, 2016 ve 2017 yıllarındaki dış ticaret fazlası sırasıyla, 91 milyar dolar, 90 milyar dolar ve 95 milyar dolar seviyesinde gerçekleşmiştir. Söz konusu dönemde G. Kore'nin ödemeler dengesi sirasıyla 105 milyar dolar, 98 milyar dolar ve 75 milyar dolar seviyesinde fazla vermiştir. ${ }^{1}$ Türkiye'nin 2015, 2016 ve 2017 yıllarındaki dış ticaret açığı ise sırasıyla, 63 milyar dolar, 56 milyar dolar ve 77 milyar dolar seviyesinde gerçekleşmiştir. ${ }^{2}$ Söz konusu dönemde Türkiye'nin ödemeler dengesi sırasıly 32 milyar dolar, 33 milyar dolar ve 47 milyar dolar seviyesinde açık vermiştir. ${ }^{3}$ G. Kore, odak sektörler seçmek ve AR-GE veya diğer teşvik politikalarını seçilen sektörlere yönlendirmek suretiyle kalkınma sürecini ilgili sektörler liderliğinde yürütmüştür. Böylelikle, seçilen odak sektörlerdeki üretim artışının, diğer sektörlere yayılması amaçlanmıştır. Her ülke kendi önceliğine, ekonomik kalkınmışlık düzeyine, kaynak yapısına ve stratejik hedeflerine göre odak sektörleri belirlemelidir. Bu çalışmada, G. Kore'de uygulanılan politika ve stratejilerin Türkiye'de de geliştirilebilmesi için çeşitli politika önerileri sunulmaktadır. Zira G. Kore'nin odak sektörlere yönelik olarak uyguladığı AR-GE ve inovasyon politikalarının incelenmesi ve bu deneyiminden yol gösterici derslerin çıkarılması, Türkiye'nin uzun dönem istikrarlı büyümeye ulaşmasına katkı sağlayacak nitelikte önemli bir örnektir.

\footnotetext{
${ }^{1}$ Ayrıntılı bilgi için bakınız: https://stats.oecd.org/Index.aspx?DataSetCode=MEI_BOP6\#

2 Ayrıntılı bilgi için bakınız: http://www.tuik.gov.tr/UstMenu.do?metod=temelist

3 https://stats.oecd.org/Index.aspx?DataSetCode=MEI_BOP6\#
} 


\section{Araştırmanın Yöntemi ve Bulgular}

$\mathrm{Bu}$ çalışma ile ithal ikameci modelden başarılı bir şekilde ihracata dayalı sanayileşme modeline geçiş sağlayan ve günümüz itibariyle dünyadaki en büyük on birinci ülke ekonomisi konumuna sahip olan G. Kore'de uygulanan ekonomi politikaları ve stratejilerin incelenmesi ve söz konusu uygulamaların Türkiye'de de geliştirilebilmesi için çeşitli politika önerilerinin sunulması amaçlanmaktadır. Zira G. Kore'nin odak sektörlere yönelik olarak uyguladığı teşvik, AR-GE ve inovasyon politikalarının incelenmesi ve bu deneyiminden yol gösterici derslerin çıkarılması, Türkiye'nin uzun dönem istikrarlı büyümeye ulaşmasına katkı sağlayacak nitelikte önemli bir örnektir. Bu doğrultuda çalışma iki temel aşamadan meydana gelmektedir. Çalışmanın ilk bölümünde ihracata dayalı sanayileşme modeli incelenmekte; ihracata dayalı sanayileşme modeline ilişkin tanım ve teorik bilgilere yer verilmektedir. Çalışmanın ikinci bölümünde ithal ikameci modelden başarılı bir şekilde ihracata yönelik sanayileşme modeline geçen G. Kore'de uygulanan ekonomik politikalar incelenmektedir. Sonuç bölümünde ise G. Kore'de uygulanılan politika ve stratejilerinin Türkiye'de geliştirilebilmesi için çeşitli öneriler sunulmaktadır.

\section{Kalkınma Modeli: İhracata Dayalı Sanayileşme Modeli}

İhracata dayalı sanayileşme modeli, liberalleşmeyi öngören ve piyasa ilişkilerinin yarattığı kapasite kullanımı, teknolojik yenilik, karşılaştırmalı üstünlükler gibi olumlu dinamik etkileri ön plana çıkaran bir yaklaşımdır. Temeli, Ricardo'nun Politik İktisat ve Vergilendirme İlkeleri Üzerine (1817) isimli eserinde yer alan karşılaştırmalı üstünlükler teorisine dayanan ihracata dayalı sanayileşme modeli, ülkenin sahip olduğu potansiyeller göz önüne alınarak, görece rekabet gücüne sahip olunan sektörlerde üretimin özendirilmesi prensibine dayanmaktadır. Model, ithal ikameci sanayileşme modelinin yanında diğer bir alternatif olarak gündeme gelmiştir. Özellikle Doğu Asya ülkelerinde uygulanan model ile bahse konu ülke ekonomilerinde yaşanan yüksek büyüme oranları göze çarpmaktadır. Model, 1980'lerde ticaret liberalizasyonu ve sanayileşme odaklı yapısıyla, birçok gelişmekte olan ülkede ekonomik büyüme ve yaşam standardını yükseltmede temel oluşturmuştur (Han ve Kaya, 2012:244). Özellikle Hong Kong ve G. Kore gibi ülkelerin katma değeri yüksek mal üretiminde ve ihracatında gösterdikleri başarı ve sağladıkları ekonomik büyüme, diğer gelişmekte olan ülkelere örnek olarak gösterilmektedir. Gelişmekte olan ülkeler çoğunlukla kalkınma çabalarına ithal ikame modeli ile başlamış ve daha sonra liberal politikalara yönelmişlerdir (Adelman, 1984). G. Kore de bu ülkelerden biridir. Zira geniş bir iç piyasaya sahip olan bahse konu ülkelerin, ithal ikamesi bakımından daha elverişli bir konumda bulunduklarını ifade etmek yerinde olacaktır. Ancak, dışa açılma ile birlikte, iç talepten çok diş talep önem kazanmaktadır. Bu durum, özellikle gelişmekte olan ülkeler açısından uluslararası rekabete açılmayı da beraberinde getirmektedir (Yeldan, 1989). Bu yeni durum, rekabet koşullarına uygun bir iç düzenlemeyi de gerekli kılmaktadır. Bu düzenlemenin en önemli gereksinimlerinden biri, ticaretin önündeki bütün engellerin kaldırılmasıdır. Bu amaçla ekonomiyi uluslararası ticarete entegre eden bir ticaret rejimi izlenmesi ve ulusal kaynak tahsisinin, ithal ikamesi yaklaşımında olduğu gibi iç talep tarafından değil uluslararası talep tarafından belirlenmesine olanak sağlanması öngörülmektedir (Linnemann, Van Dijck, Verbruggen, 1988). Bu bağlamda üretimin, uluslararası düzeyde rekabetçi olması gerekmektedir. İhracata yönelik sanayileşme modelinin temel amaçları aşağıda sıralanmaktadır;

- ülkedeki sanayi yapısını, karşılaştırmalı üstünlüklere göre, ihracat yapan girişimlerden oluşan bir yapıya dönüştürmek,

- serbest piyasa ve özel girişime dayalı bir ekonomik yapı kurmak,

- dış ticaretin liberalleşmesini ve böylece dış piyasalara açılmasını sağlamak,

- dış ticaret politikasını ihracatı özendiren bir yapıya dönüştürmek.

İhracata dayalı büyüme kavramsal olarak ekonominin dış piyasalar ekseninde yeniden yapılanmasını kapsamaktadir. Yeniden yapılanma ekonomik, finansal, teknolojik, sosyal ve kurumsal boyutludur. Dolayısıyla dış sermaye devreleri ile bağlantı çerçevesinde küresel sosyalleşme tarzının, kısacası birikim rejiminin ve regülâsyonun tüm toplum üzerindeki etkilerinin kapsaml olarak mercek altına alınması gereklidir (Sönmez, 2011a:1). 
Bu noktada, gelişmekte olan ülkelerin, G. Kore örneğinde olduğu gibi, tüm sektörlerden ziyade, yalnızca gelişme potansiyeline sahip olan seçilmiş (odak) sektörlerde üretimi özendirmeye yönelik politikalar belirlemeleri gerektiği hususunun altı çizilmelidir. Gelişmekte olan ülkelerin dış piyasalarda rekabet edebilmeleri için odak sektörlerdeki üretim tesislerinin optimum teknik kapasite ile kurulmaları ve böylelikle, ölçek ekonomisinden yararlanmaları amaçlanmaktadır. Bu yapının sağlanabilmesi için ekonomiyi uluslararası ticaretten koparmayacak bir ticaret rejimi izlenmesi ve ulusal kaynak tahsisinin, uluslararası talep tarafından belirlenmesi gerekmektedir (Kazgan, 1985:32-38). Balassa (1978) ve Michaely (1977) tarafından yapılan ihracat ve büyüme arasındaki nedensellik analizinde; ihracattaki artışın ekonomideki belli başlı sektörlerdeki üretim artışından kaynaklandığı, bu sayede, yatırımların bu sektörlere yoğunlaşarak, ülke ekonomisinin büyümesinde olumlu katkı sağladıkları sonucuna varılmıştır. Ekanayake (1999: 44) de benzer şekilde, ihracattaki artışın, ölçek ekonomisi etkisiyle pozitif dışsallık meydana getirdiğinin ve büyümeyi desteklediğin altını çizmektedir. İhracata dayalı sanayileşme modeli, ekonomik büyüme ile dış ticaret arasındaki ilişkiye dayandığından; bu model kapsamında, yatırım malı ihracatının teşvik edilmesinin ekonomik büyüme üzerinde olumlu etki yarattığı öngörülmektedir. Bu etkilerden bazılarını, "kaynakların, karşılaştırmalı üstünlüklerin bulunduğu alanlara kayması", "emeğin bol bulunduğu ülkelerde istihdamın artması", "ölçek genişlemesi", "firmaların dış rekabete açılmaları ile "verimlilik artışlarının ve yeni teknoloji kullanımının gerçekleşmesi" şeklinde belirtmek mümkündür (Krueger, 1974: 286). Bu noktada, G. Kore'nin, ihracata dayalı büyüme stratejisi ve süreçlerinin arka planında -tek etken olmasa da- ihracata yönelik sanayileşmenin bulunduğunun altını çizmekte yarar görülmektedir.

Şöyle ki, büyük ölçüde ihracattan kaynaklanan talep artışı, imalat sanayisine yönelik yatırımların artmasında belirleyici etkenlerin başında gelmektedir. Sanayileşme, çevre ülkelerde, özellikle de hızla sanayileşen Güneydoğu Asya'da endüstriyel ilişkilerin dönüşümünü açıklayan temel değgişkendir (Sönmez, 2011b:5).

G. Kore odak sektörler seçmek suretiyle, ilgili sektörlerdeki gelişmenin, ülkenin kalkınmasına yönelik olumlu katkısını göz önünde bulundurmuş; bu doğrultuda, ekonomi politikalarını bu yaklaşım çerçevesinde şekillendirmiştir. G. Kore, odak sektörleri (çelik, bilgi ve iletişim teknolojileri, elektronik ve otomotiv sektörü) koruyarak sanayileşmede büyük gelişmeler kaydetmiştir. Sanayileşme hedefi doğrultusunda politikalar geliştiren G. Kore; otomotiv sektöründe "Hyundai", "Daewoo, "Kia" gibi markalar yaratmak suretiyle sanayileşmede büyük gelişmeler kaydetmiş̧ir. Yine çelik sektöründe "Posco", elektronik sektöründe "Samsung", "LG" gibi markalara çeşitli teşvikler sağlamak suretiyle ülkenin kalkınmasında önemli adımlar atmıştır. Öyle ki kalkınma için dünya ölçeğinde rekabet edebilecek teknoloji yatırımları büyük önem arz etmektedir. Schumpeter (1942:259)'in "yaratıcı yıkım" teorisine göre, yenilikçi olmayan firmaların ve ekonomilerin rekabet gücü azalmaktadır. Bu bağlamda, günümüz gelişmiş ülkelerinin kalkınma sürecinde, teknolojik gelişmenin büyük etkisi olduğunu ifade etmek yerinde olacaktır. Schumpeter (1942), kârın kaynağının inovasyon olduğunu vurgulamış ve inovasyonu girişimcilik ile ilişkilendirmiştir. Schumpeter (1942:259)'e göre, inovasyon, iktisadi kalkınmanın temel gücünü oluşturmaktadır. Zira inovasyon ve rekabetçilik, rekabetçilik ve kalkınma ile inovasyon ve kalkınma arasında güçlü ilişkiler bulunmaktadır (OECD, 2012). Gelişmiş ülkelerde, küreselleşme, rekabetteki artış, bilişim ve iletişim teknolojilerindeki hızlı ilerleme, hızlı bilimsel ve teknolojik gelişmeler gibi faktörlerin etkisiyle firmalar, daha yüksek seviyelerde AR-GE yatırımlarına yönelmektedirler. Dünya piyasasında rekabetçi olabilmek, teknolojik gelişmeler ile yakından ilişkili olduğundan birçok firma, kaynaklarını AR-GE yatırımlarına yönlendirmektedir. Öyle ki, bu noktada, gelişmekte olan ülke devletlerinin AR-GE yatırımlarını destekleme konusundaki rolünün son derece stratejik olduğunun altını çizmekte yarar görülmektedir. Yukarıda da ifade edilmiş olduğu üzere, kalkınmayı hızlandıran en önemli unsurların başında AR-GE ve inovasyon yatırımlarının geldiği olgusuna en yerinde örneklerden bir tanesi G. Kore'dir. G. Kore, 1980'lerin sonu ile 1990'ların başından itibaren ARGE yatırımlarını hızlandırmış; böylelikle teknolojik yapılanmasında büyük gelişim sağlamıştır. Öyle ki G. Kore, AR-GE politikalarının yönlendirilmesine ilişkin odak sektörler seçerek, bu sektörlerin gelişimine hız kazandırılmasını sağlamıştır (Arslanhan ve Kurtsal, 2010). Bu bağlamda, ithal ikameci politikalarla başlayarak, ihracata dayalı sanayileşme modeline geçiş sağlamak suretiyle kalkınma hamlesi gerçekleştiren G. Kore'nin kalkınma modelinin incelenmesinde fayda görülmektedir. Öyle ki 1962 yılında GSMH'si 2.3 milyar dolar, ihracatı 55 milyon dolar ve ithalatı 390 milyon dolar ve kişi başına düşen geliri 87 dolar olan G. Kore (Chung, 2011), günümüz itibariyle dünyadaki en büyük on birinci ülke ekonomisi konumuna sahip bulunmaktadır (World Bank, 2019). 


\section{Güney Kore}

G. Kore, 1948 yılında Japonya'dan bağımsızlığını ilan ettiği dönemde, dünyanın en yoksul ülkelerinden biri konumunda bulunmaktadır. O dönemde ağırlıklı olarak tarım ülkesi olan G. Kore'nin, bugün ulaşmış olduğu başarıyı, Konfüçyus öğretisi başta olmak üzere; 1961 yılında askeri darbe ile iktidara gelmiş olan Park Chung Hee yönetimine borçlu olduğunu ifade etmek yerinde olacaktır. G. Kore'nin bu dönemde ortaya koymuş olduğu ekonomik gelişme, Park yönetiminin uyguladığı ekonomik politikalarla bağlantılıdır. Öyle ki ülke menfaatlerinin ön planda tutulduğu -Singapur'un lideri Lee Kuan Yew modelinde olduğu gibi -bir diktatör rejimi, koşulsuz tehlikeli ve kötü olarak değerlendirilmemelidir (Eun, 2019). Nitekim 1962 yılında Park da ekonomik büyümeyi yönlendirmek için teknokratlar tarafından görevlendirilen bir Ekonomik Planlama Kurulu oluşturmuş ve beş yıllık kalkınma planları ile ekonomik büyümeyi hedeflemiştir (Seth, 2017). Bu doğrultuda G. Kore, ilk beş yıllık kalkınma planı çerçevesinde, hafif sanayi ürünleri üretimine öncelik vermek suretiyle bu dönemde, yaklaşık yüzde dokuz oranında bir ekonomik büyüme gerçekleştirmiştir. G. Kore, kalkınma hamlesine, ülke içinde faaliyet gösterdiği alanda en başarılı olan girişimcileri seçerek ve söz konusu girişimcileri destekleyerek başlamıştır. G. Kore devleti tarafından desteklenen girişimcilere örnek olarak Hyundai'nin kurucusu Chung Ju-yung ve Posco'nun kurucusu Park Tae-joon verilebilir. 1961-1970 yılları arasında ithal ikame model uygulayan G. Kore de, diğer Asya ülkeleri gibi 1997 yılında baş gösteren krizden ciddi boyutta etkilenmiş ve ülkenin önde gelen firmalarından birçoğu iflas etmiştir. Böylelikle 1998 yılında G. Kore ekonomisi yaklaşık yüzde yedi oranında küçülmüştür. G. Kore bu dönemde yurt dışından fon sağlama konusunda başarısız kalmış ve bu doğrultuda Uluslararası Para Fonu (IMF) ile 58 milyar dolar tutarında kredi paketini de içeren stand by anlaşması imzalamıştır (Coe ve Kim, 2002). Yine bu dönemde Ekonomik Kalkınma ve İşbirliği Örgütü (OECD) ve Dünya Ticaret Örgütü (WTO)'ya katılmak suretiyle libarelleşmeye yönelik politikalara hız vermiştir. G. Kore, bu dönemde, ithal ikame modelinden ihracata dayalı kalkınma modeline yönelik politikalara ağırlık vermek suretiyle ve küresel değer zincirlerinden daha fazla pay alma hedefiyle dünyaya açılmaya başlamış ve böylelikle bahse konu dönemde yaşadığı krizi fırsata çevirmeyi başarmıştır. G. Kore'nin ekonomik kalkınmasının temelini, devletin, bireylerin teknik beceriler edinmesine ve bu doğrultuda ters mühendislikle yeni teknolojiler üretmesine yönelik attığı adımlar oluşturmuştur. G. Kore planlı dönem içinde yaratıcılığı, araştırma ve teknik bilginin yayılmasını teşvik etmek amacıyla Kore Bilim ve Teknoloji Enstitüsü gibi birçok enstitü kurmuştur (Seth, 2017). G. Kore'nin kalkınma modelinde insan gücüne yapılan yatırımlar önemli rol oynamaktadır. Öyle ki G. Kore, hızlı ekonomik gelişimi ve büyüme modeliyle küresel ekonomide birçok dinamikleri etkileyerek dünyanın ilgi odağı haline gelmiştir. İhracata yönelik sanayileşme modelinde Schumpeterci rejime, bütünüyle olmasa da, önemli ölçüde geçiş yapan G. Kore, bu yönüyle de incelemeye değer bir örnektir (Sönmez, 2011b:1). G. Kore günümüzde, ekonomisini taşıdığı noktaya, insan gücüne ve eğitime yatırım yapmak suretiyle ulaşmış ve bu sayede, kayda değer bir büyümenin yanı sıra, teknolojik açıdan da önemli bir gelişim kaydetmiştir. Bu başarıların temelinde, AR-GE yatırımlarının yanı sıra, doğrudan yabancı yatırımlara (DYY) mesafeli yaklaşımı da önemli rol oynamaktadır.

Güney Kore'nin inovasyon sürecini imitasyon, dönüşüm ve inovasyon olarak üç aşamaya ayırmak mümkündür. (Oğuztürk, Özbay ve Pehlivan, 2017) Öyle ki G. Kore, odak sektörlere ilişkin sanayi yatırımlarına yönelik kaynağı DYY'den ziyade yurt dışından sağlanan uzun vadeli fonlarla desteklemek suretiyle yurt içindeki girişimcileri desteklemiş ve bu sayede özgün bir kalkınma modeli ortaya koymuştur. Bir başka ifadeyle sermaye birikimi sağlayamayan G. Kore, sermaye birikimi için DYY'leri ülkeye çekmeye yönelik politikalar uygulamaktansa; yurt içindeki girişimcileri desteklemek suretiyle tasarruf ve sermaye birikimini özendiren politikalar uygulamıştır. G. Kore, çoğunlukla aile şirketi olan milliyetçi ve sadık yerli girişimcilere çeşitli teşvikler sağlamak suretiyle, söz konusu şirketlerinin inovasyon ruhundan faydalanmayı tercih etmiştir. Bu sayede söz konusu şirketler zamanla emek yoğun üretim yapan basit işletmelerden, teknolojiyi içselleştiren dünya çapında büyük markalar yaratan şirketler halini almıştır. Bu sayede G. Kore, yurt içindeki sanayilere dünya pazarını hedef göstermek suretiyle, imalat sanayisinin kompozisyonunu önemli ölçüde değiştirmiş; üretim ve ihracatta yüksek katma değer getiren ileri teknolojili ürünlere doğru hızlı geçiş sağlamıştır. Bu girişimler Korece "chae" (zenginlik) ve "bol" (grup/ takım) kelimelerinden oluşan "chaebol" olarak adlandırılmaktadır. Hyundai ve Samsung, chaebol'lerin en temel örneklerindendir.

G. Kore'de 1980'lerin sonundan itibaren emek yoğun sanayiden, öncelikli olarak sermaye yoğun hafif sanayiye ve sonrasında ileri teknolojili sanayiye doğru bir dönüşüm gözlemlenmektedir (OECD, 2009). G. 
Kore'nin bilim, sanayi ve teknoloji politikaları Tablo 1'de sunulmaktadır. Bahse konu tablonun incelenmesi neticesinde 1960'lı yıllardan itibaren uygulanan tüm ekonomi politikalarında AR-GE ve teknolojinin ağırlığı dikkat çekmektedir. Öyle ki 1960 yılında yerli AR-GE kapasitesinin geliştirilmesi ile başlayan süreç, günümüzde G. Kore'yi inovasyon geliştirme konusunda liderliğe taşımıştır. Dünya Fikri Mülkiyet Örgütü tarafından 2018 yılında yayınlanan küresel inovasyon endeksine göre G. Kore, 126 ülke arasında 12. sırada bulunmaktadır. (WIPO, 2018) Yine söz konusu rapora göre G. Kore, GSYİH'den AR-GE yatırımlarına ayırdığı pay itibariyle yüzde 4,2'lik oranla (İsrail'in ardından) dünyada ikinci sırada bulunmaktadır.

Tablo 1: G. Kore'nin Sanayi, Bilim ve Teknoloji Politikaları

\begin{tabular}{|c|c|c|c|c|}
\hline & $1960-1980$ & $1980-1990$ & $1990-2000$ & 2000 ve sonras 1 \\
\hline $\begin{array}{l}\text { Bilim ve } \\
\text { Teknoloji } \\
\text { Politikaları }\end{array}$ & $\begin{array}{l}\text { - İlk devlet araştırma } \\
\text { enstitüsü Kore } \\
\text { Bilim ve Teknoloji } \\
\text { Enstitüsü (KIST) ve } \\
\text { Bilim ve Teknoloji } \\
\text { Bakanlığı } \\
\text { (MoST)'un } \\
\text { kurulması } \\
\text { • İlk Bilim ve } \\
\text { Teknoloji Teşvik } \\
\text { Yasası'nın } \\
\text { yürürlüğe girişi } \\
\text { (1967) (vergi } \\
\text { muafiyetleri) }\end{array}$ & $\begin{array}{l}\text { - Ulusal AR-GE } \\
\text { Programı (1982) } \\
\text { • “Daedeok Science } \\
\text { Town”un } \\
\text { kurulması } \\
\text { - Özel firmaların } \\
\text { AR-GE için teşviki } \\
\text { (vergi teşvikleri, } \\
\text { finansal teşvikler) }\end{array}$ & $\begin{array}{l}\text { - Ulusal Bilim } \\
\text { Teknoloji } \\
\text { Konseyinin } \\
\text { kurulması } \\
\text { - Beş yıllık } \\
\text { inovasyon planı } \\
\text { (1997) } \\
\text { • Bilim ve Teknoloji } \\
\text { Vizyonu 2025 } \\
\text { (1999) } \\
\text { - Üniversite } \\
\text { araştırmaları } \\
\text { teşviki }\end{array}$ & $\begin{array}{l}\text { - İlk ulusal teknoloji } \\
\text { yol haritasının } \\
\text { hazırlanması } \\
\text { - Bilim ve Teknoloji } \\
\text { Bakanlığı'nın } \\
\text { yeniden } \\
\text { yapılandırılması }\end{array}$ \\
\hline $\begin{array}{l}\text { Sanayii } \\
\text { Politikasının } \\
\text { Ana Hatları }\end{array}$ & $\begin{array}{l}\text { - 1960'lar; İthal } \\
\text { ikameci sanayilerin } \\
\text { gelişimi, ucuz iş } \\
\text { gücü avantajı ile } \\
\text { tarım tekstil gibi } \\
\text { sektörlerin ön } \\
\text { planda olması } \\
\text { - DYY ve teknoloji } \\
\text { transferleri } \\
\text { - 1970'ler; Ağır } \\
\text { sanayiye giriş } \\
\text { - Yerli AR-GE } \\
\text { kapasitesinin } \\
\text { geliştirilmesinin } \\
\text { teşviki }\end{array}$ & $\begin{array}{l}\text { • Teknoloji yoğun } \\
\text { sektörlere kayma } \\
\text { • Tek başına } \\
\text { teknoloji transferi } \\
\text { ve araştırma } \\
\text { enstitülerinin } \\
\text { yetersiz kalması, } \\
\text { firmaların kendi } \\
\text { AR-GE yapılarını } \\
\text { kurmaları/ } \\
\text { gelişmelerinin } \\
\text { teşvik edilmesi }\end{array}$ & $\begin{array}{l}\text { - Yüksek-teknoloji } \\
\text { sektörlerinde } \\
\text { gelişme } \\
\text { • Talebe yönelik } \\
\text { teknoloji geliştire } \\
\text { sisteminin } \\
\text { güçlendirilmesi } \\
\text { - Asya krizi ve } \\
\text { sonrasında şirket } \\
\text { yapıları ile ilgili } \\
\text { gelen } \\
\text { düzenlemeler ve } \\
\text { yaşanan değişimler }\end{array}$ & $\begin{array}{l}\text { - Var olan ileri } \\
\text { teknoloji } \\
\text { sektörlerinde } \\
\text { ilerlemenin yanı } \\
\text { sıra biyoteknoloji } \\
\text { ve nanoteknolojiye } \\
\text { giriş } \\
\text { - Geleneksel KOBİ } \\
\text { yapılandırılmasınd } \\
\text { an farklı AR-GE } \\
\text { temelli KOBI'lerin } \\
\text { yaygınlaşması }\end{array}$ \\
\hline
\end{tabular}

Kaynak: Arslanhan ve Kurtsal, 2010:3

Tablo 2'de 1960 ile 1990'lar arasında G. Kore'de teknolojik kapasite oluşturma yönündeki yapılanma özetlenmektedir. Bahse konu tablonun incelenmesi neticesinde 1960'lı yıllardan itibaren sınai ürün ihracının başlaması, ileri ve çekirdek teknolojinin öğrenilmesi ve yüksek nitelikli ürün teknolojisine yönelim dikkat çekmektedir. 
B. Erkök 11/3 (2019) 1401-1416

Tablo 2: Teknoloji Kapasite Oluşturma Süreci

\begin{tabular}{|c|c|c|c|}
\hline Dönem & Gelişme Süreci & Teknoloji Transferi & Üretim ve AR-GE \\
\hline $1960-1970$ & $\begin{array}{l}\text { Amaç: Üretim tabanı } \\
\text { oluşturulması } \\
\text { Özellikler: İthal teknolojiye } \\
\text { aşırı bağımlılık }\end{array}$ & $\begin{array}{l}\text { Kullanıma hazır } \\
\text { Teknoloji: } \\
\text { Anahtar teslim } \\
\text { fabrikalar, montaj } \\
\text { sanayii }\end{array}$ & $\begin{array}{l}\text { Ucuz üretim } \\
\text { OEM/ (orijinal donatım } \\
\text { üretimi) kullanımı; yerel AR- } \\
\text { GE eksik veya yetersiz }\end{array}$ \\
\hline 1980’lerin Başları & $\begin{array}{l}\text { Amaç: Özgüvenin } \\
\text { geliştirilmesi } \\
\text { Özellikler: İthal ikamesi, } \\
\text { üretimde kullanılan parçalar } \\
\text { ve ara girdilerin yerel olarak } \\
\text { üretimi }\end{array}$ & $\begin{array}{l}\text { Kullanıma hazır } \\
\text { olamayan teknoloji: } \\
\text { Ara girdi üretiminde } \\
\text { kullanılan teknoloji, } \\
\text { İşletim teknolojisi }\end{array}$ & $\begin{array}{l}\text { OEM/yerli marka: } \\
\text { Yüksek oran } \\
\text { Ürün geliştirilmesi }\end{array}$ \\
\hline $\begin{array}{c}\text { 1980'lerin Sonları } \\
\text { 1990'lar }\end{array}$ & $\begin{array}{l}\text { Amaç: Yerel pazarın } \\
\text { genişletilmesi yoluyla } \\
\text { ihracatın artırılması } \\
\text { Özellikler: Sınai ürün } \\
\text { ihracının başlaması, ileri ve } \\
\text { çekirdek teknolojinin } \\
\text { öğrenilmesi }\end{array}$ & $\begin{array}{l}\text { Nano teklonoji } \\
\text { Kontrol teknolojisi } \\
\text { Proje teknolojisi, } \\
\text { Yüksek nitelikli ürün } \\
\text { teknolojisi }\end{array}$ & $\begin{array}{l}\text { OEM/yerli marka: Düşük } \\
\text { oran } \\
\text { Ürün inovasyonu } \\
\text { Üretim sürecinin } \\
\text { geliştirilmesi }\end{array}$ \\
\hline
\end{tabular}

Kaynak: UNIDO, 2002:13; Sönmez, 2011:1

G. Kore 1960'l1 yıllarda üretim sürecinde ülke için "modern", gelişmiş ülkeler için "eskimiş" teknolojiyi kullanmaya başlamıştır. Bahse konu teknoloji kullanımı dış yardım ve borçlanma ile merkez ülkelerde eskimiş olan sanayilerin anahtar teslim fabrikalar biçiminde G. Kore'ye aktarılması biçiminde gerçekleşmiştir. Bu model ile G. Kore 1970'lerin sonları ile 1980'lerin başlarında ekonomik büyüme aşamasını yakalamış; 1980'lerde ağır sanayide önemli yol aldıktan sonra 1990'larda yüksek teknolojiye dayalı sınai yapıyı kurma aşamasına ulaşmıştır. Nitekim 1960'lı yıllarda G. Kore sanayisi montaja dayalı olmakla birlikte; uygulamaya konulan teknolojik gelişme stratejisi çerçevesinde, bilim ve teknolojinin geliştirilmesi için hukuksal ve kurumsal alt yapının oluşturulması, bu alandaki eğitimin yaygınlaştırılması ve ülkeye yüksek teknoloji transferinin kolaylaştırılması amaçlanmıştır. 1970'lerde stratejik öneme sahip odak sektörler bilimsel ve teknolojik eğitim ve öğretimin niteliğinin yükseltilmesi, ithal teknolojilerin uyarlanması ve geliştirilmesi doğrultusunda özel sektörde araştırma birimlerinin kurulması ve sanayide teknolojik araştırmaların güçlendirilmesi ve geliştirilmesi olarak belirlenmiştir (Sönmez, 2011b). 1980'lerde ise teknoloji transferinin özendirilmesi; bu çerçevede, ülke dışında önemli sayıda yüksek nitelikli işgücü istihdamı, ülke içinde teknolojik donanıma sahip işgücünün yetiştirilmesine odaklanmıştır. G. Kore'nin sanayileşme sürecinin teknolojik gelişme, inovasyon ve bilimsel araştırma tarafından yönlendirildiği görülmektedir (Sönmez, 2011b). Aşağıda yer alan Tablo 3'de sanayileşme düzeyi ile teknoloji transferi arasındaki bağlantı ortaya konulmaktadır. Bahse konu tabloda, 1960'lı yıllardan itibaren uygulanan tüm ekonomi politikalarında teknolojiye verilen önem çerçevesinde vasıfsız iş gücünün, bilim insanı ve mühendislere doğru gelişimi dikkat çekmektedir. 
B. Erkök 11/3 (2019) 1401-1416

Tablo 3: Güney Kore'de Teknoloji Transferi

\begin{tabular}{|l|l|l|l|l|}
\hline Y11 & Hâkim Sanayi & Çekirdek Gücü & Teknoloji Boyutu & $\begin{array}{l}\text { Teknoloji Transfer } \\
\text { Mekanizması }\end{array}$ \\
\hline 1950 & Tarım & Vasıfsız işgücü & Modern öncesi & - \\
\hline 1960 & Zanaat & Vasıflı işgücü & Aşınan/ Eskiyen & $\begin{array}{l}\text { Anahtar teslim ve } \\
\text { proje }\end{array}$ \\
\hline 1970 & Hafif Sanayi & Vasıflı teknik işgücü & Aşınan ve Olgunlaşan & Patent (Kısmen) \\
\hline 1980 & Ağır Sanayi & Mühendisler & Olgunlaşan & Patent \\
\hline 1990 & $\begin{array}{l}\text { Yüksek teknoloji } \\
\text { kullanan sanayi }\end{array}$ & $\begin{array}{l}\text { Mühendisler ve bilim } \\
\text { insanları }\end{array}$ & Gelişen & Patent ve ortak yatırım \\
\hline
\end{tabular}

UNIDO, 2002:31; Sönmez, 2011:12

Tablo 1, Tablo 2 ve Tablo 3'ün incelenmesi neticesinde, G. Kore' de hafif sanayiden yüksek teknoloji kullanan sanayiye geçiş sürecinde teknoloji transferinin kullanım biçimi gözlemlenmektedir. Şöyle ki üretim, zamanla teknoloji transferine olan bağımlılı̆̆ geride bırakmış; teknoloji üretimi, inovasyon ve AR-GE'nin şekillendirdiği bir sanayileşme sürecine girmiştir. Sanayileşmede ve AR-GE'de alınan yola paralel olarak çekirdek iş gücünün niteliksel olarak dönüştügü gözlemlenmektedir (Sönmez, 2011b). 1980'li yılların sonundan itibaren, teknoloji ve eğitim odaklı politikalar izleyen G. Kore'de hükümetin düzenleyici eli, piyasaların düzenleyici eliyle yer değiştirmeye başlamıştır (Chang, Seok ve Baker, 2008:197). Bu noktada, G. Kore tarafından izlenen kalkınma politikalarının etkisini ortaya koyabilmeyi teminen en fazla ihraç ürünlerin yıllara göre seyrini incelemekte fayda görülmektedir.

Tablo 4: Güney Kore'nin Yıllar İtibariyle İhraç Ürünleri ${ }^{4}$

\begin{tabular}{|l|l|l|l|l|l|}
\hline Sıra & \multicolumn{1}{|c|}{$\mathbf{1 9 8 0}$} & \multicolumn{1}{c|}{$\mathbf{1 9 9 0}$} & \multicolumn{1}{c|}{$\mathbf{2 0 0 0}$} & \multicolumn{1}{c|}{ 2007 } & \multicolumn{1}{c|}{ 2017 } \\
\hline 1 & Konfeksiyon & Konfeksiyon & Yarı İletkenler & Otomotiv & Elektronik Ürünler \\
\hline 2 & Demir Çelik & Yarı İletkenler & Otomotiv & Yarı İletkenler & $\begin{array}{l}\text { Bilgisayar, Makine ve } \\
\text { Cihazlar }\end{array}$ \\
\hline 3 & Gemi Yapımı & Ayakkabı & Gemi Yapımı & Telekomünikasyon & Araç, taşıt \\
\hline 4 & Sentetik Fiber & Gemi Yapımı & Cep Telefonu & Gemi Yapımı & Gemi \\
\hline 5 & Ses Aletleri & $\begin{array}{l}\text { Video } \\
\text { Donanımları }\end{array}$ & Sentetik Fiber & Petrol Ürünleri & Mineral Yakıtlar \\
\hline 6 & Araba Lastiği & Demir Çelik & $\begin{array}{l}\text { Otomotiv Yedek } \\
\text { Parça }\end{array}$ & TV Ekranı & Plastik ve Mamuller \\
\hline 7 & Ağaç ürünleri & Sentetik Fiber & TV Ekranı & Araba Parçaları & $\begin{array}{l}\text { Optik Alet ve } \\
\text { Cihazlar }\end{array}$ \\
\hline 8 & $\begin{array}{l}\text { Diğer } \\
\text { Ürünler }\end{array}$ & Bilgisayarlar & Telekomünikasyon & Bilgisayarlar & $\begin{array}{l}\text { Organik Kimyasal } \\
\text { Ürünler }\end{array}$ \\
\hline 9 & $\begin{array}{l}\text { Yarı } \\
\text { İletkenler }\end{array}$ & Ses Aletleri & Bilgisayarlar & $\begin{array}{l}\text { Görsel Donanım } \\
\text { Aletleri }\end{array}$ & Demir Çelik \\
\hline 10 & Video & Otomotiv & Renkli Televizyon & Elektronik Ürünler & Demir Çelikten Eşya \\
\hline
\end{tabular}

Kaynak: Korean International Trade Association ve Chung, 2011 verilerinden derlenmiştir.

Tablo 4'ün incelenmesi neticesinde, 1980 'lerde ihraç edilen ürünlerin başında tekstil ürünleri yer almakta iken 2007 yılına gelindiğinde ilk sırayı otomotiv sektörünün, 2014 yılında ise elektronik ürünlerinin aldığ1

4 Ayrıntılı bilgi için bakınız: http://www.worldstopexports.com/south-koreas-top-10-exports/ (04.10.2018) 
anlaşılmaktadır. Bu doğrultuda, 1980'lerdeki emek yoğun ürünlerin, 2000'li yıllara gelindiğinde yerini teknoloji yoğun ürünlere bıraktığı gözlemlenmektedir. G. Kore'de, gerek bilim ve teknoloji politikaları gerekse sanayi politikaları ile imalat sanayinin kompozisyonunda da yıllar içerisinde önemli değişimler dikkat çekmektedir. Gida, içecek ve tekstil gibi emek yoğun sanayiden, öncelikli olarak sermaye yoğun hafif sanayiye ve sonrasında da, bilişim teknolojileri ile ileri teknolojili sanayiye doğru hızlı bir değişim gözlemlenmektedir. (OECD, 2009) Tablo 6 ve Tablo 7'de G. Kore'nin 2015, 2016 ve 2017 yıllarına ait ihracat, ithalat ve denge rakamları sunulmaktadır. Bahse konu tabloların incelenmesinden, G. Kore'nin ihracat pazarında ilk üç sırayı Çin, ABD ve Vietnam'ın; ithalatta ise Çin, ABD ve Japonya'nın aldığı anlaşılmaktadır. G. Kore ihracatının yüzde 25'ini ileri teknoloji ürünleri oluşturmaktadır (Oğuztürk, Özbay ve Pehlivan, 2017). Söz konusu ülkenin 2015, 2016 ve 2017 yıllarındaki dış ticaret fazlası sırasıyla, 91 milyar dolar, 90 milyar dolar ve 95 milyar dolar seviyesinde gerçekleşmiştir. Söz konusu dönemde G. Kore'nin ödemeler dengesi sırasıyla 105 milyar dolar, 98 milyar dolar ve 75 milyar dolar seviyesinde fazla vermiştir. ${ }^{5}$

Tablo 5: $\quad$ İhracat Yapılan İlk Beş Ülke (milyar dolar) ${ }^{6}$

\begin{tabular}{|l|c|c|c|}
\hline Ülke & $\mathbf{2 0 1 5}$ & $\mathbf{2 0 1 6}$ & $\mathbf{2 0 1 7}$ \\
\hline Çin & 137 & 124 & 142 \\
\hline ABD & 69 & 66 & 69 \\
\hline Vietnam & 28 & 33 & 48 \\
\hline Hong Kong & 30 & 32 & 39 \\
\hline Japonya & 25 & 24 & 27 \\
\hline Dünya & 526 & 495 & 574 \\
\hline
\end{tabular}

Kaynak: Korea Customs Service, 2018

Tablo 6: İthalat Yapılan İlk Beş Ülke (milyar dolar)

\begin{tabular}{|l|c|c|c|}
\hline İhracatçı Ülkeler & $\mathbf{2 0 1 5}$ & $\mathbf{2 0 1 6}$ & $\mathbf{2 0 1 7}$ \\
\hline Çin & 90 & 87 & 98 \\
\hline Japonya & 46 & 47 & 55 \\
\hline ABD & 44 & 43 & 51 \\
\hline Almanya & 21 & 19 & 20 \\
\hline Suudi Arabistan & 20 & 16 & 20 \\
\hline Dünya & 436 & 406 & 478 \\
\hline
\end{tabular}

Kaynak: ITC, 2015

Tablo 7: Dış Ticaret Dengesi (milyar dolar)

\begin{tabular}{|c|c|c|c|}
\hline \multirow{2}{*}{ Diş Ticaret Dengesi } & $\mathbf{2 0 1 5}$ & $\mathbf{2 0 1 6}$ & $\mathbf{2 0 1 7}$ \\
\cline { 2 - 4 } & 91 & 90 & 95 \\
\hline
\end{tabular}

Kaynak: ITC, 2015

Bu noktada G. Kore'nin, ekonomik kalkınmadaki başarısının, kendine özgü bir model çerçevesinde, inovasyon ve AR-GE'de ortaya koymuş olduğu gelişim temelinde yükseldiğini ve bu yönüyle, dünyada ilgi çeken bir ülke olduğunu ifade etmek yerinde olacaktır. 1980'lere kadar kişi başına düşen GSYİH ve AR-GE faaliyetlerine yapılan harcamalar açısından alt sıralarda yer alan G. Kore, 1980'lerde bu gidişatı tamamen tersine çevirmiştir. Öyle ki 1960 yılında 945 dolar olan kişi başına düşen GSYİH, 1980 yılında 3,7 bin dolar,

5 Ayrıntılı bilgi için bakınız: https://stats.oecd.org/Index.aspx?DataSetCode=MEI_BOP6\#

6Ayrıntılı bilgi için bakınız: http://www.intracen.org/country/republic-of-korea/ http://www.customs.go.kr/kcshome/trade/TradeCountryList.do (04.08.2018) 
2000 yılında 15 bin dolar ve 2017 yılında 26 bin doların üzerinde olarak gerçekleşmiştir. G. Kore 26 bin doların üzerinde olan kişi başına düşen gelir düzeyiyle birçok gelişmiş ülkeyi de geride bırakmaktadır. Gelişmişlik göstergelerinin en önemli maddelerinden birisi de GSYİH içindeki sanayi, tarım ve hizmet sektörü oranıdır. Göstergeler içinde hizmet sektörünün yüksek, tarım sektörünün ise en düşük pay alması beklenmekte olup G. Kore göstergeleri incelendiğinde bu önemli şartı da sağladığı görülmektedir (Oğuztürk Özbay ve Pehlivan, 2017). Yukarıda da ifade edildiği gibi G. Kore, ekonomisini taşıdığı bu noktaya beşeri sermayeye yaptığı yatırım ve AR-GE'ye atfettiği önem sayesinde ulaşmıştır. G. Kore AR-GE'nin GSYİH içindeki oranı bakımından G-20 ülkeleri arasında en yüksek ülke konumunda bulunmaktadır (Oğuztürk, Özbay ve Pehlivan, 2017). Bu doğrultuda, söz konusu ülke ortaya koyduğu inovasyon odaklı kalkınma modeli ile zaman içerisinde kayda değer bir büyümenin yanı sıra, teknolojik açıdan da önemli gelişimler kaydetmiştir (Arslanhan ve Kurtsal, 2010). G. Kore söz konusu kalkınma modeli çerçevesinde, gerek inovasyon alanındaki girişimleri, gerek insan kaynaklarına verdiği önem sayesinde, orta-gelir tuzağından da sıyrılmayı başarmıştır. Bu başarıların temelinde de gelişmiş ülkeler ile rekabet edebilecek bir konuma ulaşma yolunda uyguladığı özgün politikalar yer almaktadır. Bu politikalar arasında ön plana çıkan en önemli husus kuşkusuz AR-GE sisteminin geliştirilmesi ve insana yapılan yatırımlardır. G. Kore'nin 1980'lerde yaşadığı dönüşümün arkasında AR-GE'nin önemli bir kısmını özel sektör eliyle güçlendirmesi yatmaktadır. Bu bağlamda, özel sektörün uluslararası pazarda rekabetçiliğinin artırılması hedeflenmiştir. G. Kore'nin ekonomik kalkınmasını hızlandıran en önemli unsurlardan biri de teknoloji geliştirme konusunda gösterdiği başarıdır. G. Kore özellikle 1990'ların başından itibaren ülkenin ve sanayinin ihtiyaçları doğrultusunda çalışmalar yapılmasına yönelik politikalar uygulanmıştır. G. Kore'nin dünyadaki gelişmeleri hızla takip etmek suretiyle nanoteknoloji ve biyoteknoloji alanlarına yaptığı yatırımları artırdığı ve bu yatırımlara stratejik öncelikler verdiği gözlemlenmektedir. G. Kore'de kalkınma politikalarının koordinasyonunu sağlayan Ekonomik Planlama Kurulu (EPK) devletle özel sektörün ortak hedeflerde birleşmesinde önemli rol oynamaktadır (Kim, 2006: 12; Lee, 2006:84). G. Kore'nin kalkınmasını hızlandıran bir diğer önemli etken de seçilen odak sektörler bazında AR-GE politikalarının uygulanmasıdır. Öyle ki, G. Kore,1990'lı yıllara kadar dış dünyadaki teknolojiye erişim ve teknolojiyi millileştirme odaklı beş yıllık kalkınma planları çerçevesinde odak sektörler belirlemiş ve kalkınma hamlesini bahse konu sektörler öncülügünnde hızlandırmayı amaçlamıştır. Yukarıda da ifade edilmiş olduğu üzere, G. Kore'nin kalkınma sürecinde en fazla dikkat çeken bir başka husus da DYY'lere olan mesafeli yaklaşımıdır. Şöyle ki G. Kore, teknoloji transferini yabancı yatırımcılar kanalıyla sağlamaktan ziyade yurt içinde tesis edilmesine yönelik milliyetçi politikalar izlemiştir. Bu bağlamda, G. Kore, milliyetçi kalkınma modeli çerçevesinde, ihracat hedeflerini tutturma, yabancilara ait hisselerde sinırlama, şirket kurmada belli başlı zorunluluklar gibi yabancı yatırımcılara yönelik birtakım kısıtlamalar uygulamıştır. (Chung, 2011)Bu sebeple G. Kore'de gözlenen ekonomik gelişmede yabancı yatırımcı rolünün, diğer gelişmekte olan ülkelere göre nispeten az olduğunu ifade etmek yerinde olacaktır. Bunun yanı sıra, G. Kore'de gözlenen teknoloji gelişiminde, yukarıda belirtilen şartlar dâhilinde faaliyet gösteren yabancı yatırımcılar tarafından yapılan anahtar teslimi fabrika, ithal edilmiş olan teknoloji ürünü üretim tezgâhlarının ve makinalarının ters mühendislikle (reverse engineering) taklit edilmesi gibi yöntemlerin önemli rol oynadıkları gözlemlenmektedir. (Chung, 2011) Bu bağlamda, G. Kore'de uygulanan sanayileşme politikaları kapsamında, yabancı şirketlerin G. Kore'de bilfiil yatırım yapmalarından ziyade, teknoloji lisanslama yoluna gittiği dikkat çekmektedir.

G. Kore'de gözlemlenen ekonomik ve finansal serbestleşmeye paralel olarak, devletin finans sektörüne yönelik kontrolü gevşemeye başlamış; iç pazar kısmi oranda ithal mallara açılmış ve üretim amacıyla yabancı yatırımcıyı ülkeye çekebilecek politikalar uygulanmıştır (Kim ve Rahlman, 1999: 188). G. Kore'de yabancı yatırımcıya karşı uygulanan yatırım sınırlamaları 1980'li yılların ikinci yarısından sonra peyderpey kaldırılmış olup, gelinen noktada, Japonya ve ABD, G. Kore'deki toplam yabancı yatırımların yüzde seksenine ve teknoloji lisanslarının yüzde yetmişine sahip hale gelmiştir (Cyhn, 2002:34). G. Kore Bilim ve Teknoloji Politikaları Enstitüsü tarafından gerçekleştirilen araştırmada, AR-GE ve inovasyon için toplam 259 program sunulduğunun altı çizilmektedir (Chung, 2011). G. Kore'de devlet tarafından sunulan tüm teşvikler içinde AR-GE yatırımlarının payının yüzde otuz, teknoloji transferi payının yüzde on üç, eğitimin payının ise yüzde on bir olduğu gözlemlenmiştir. Bu bağlamda, G. Kore'de patent sayısında önemli artış meydana geldiğini ifade etmek yerinde olacaktır. G. Kore'deki patent sayılarının gelişimi Tablo 8'de sunulmaktadır. 
B. Erkök 11/3 (2019) 1401-1416

Tablo 8: G. Kore'deki Patent Sayılar1 ${ }^{7}$

\begin{tabular}{|l|l|l|l|l|l|l|l|l|}
\hline Y11 & $\mathbf{1 9 5 0}$ & $\mathbf{1 9 6 0}$ & $\mathbf{1 9 7 0}$ & $\mathbf{1 9 8 0}$ & $\mathbf{1 9 9 0}$ & $\mathbf{2 0 0 0}$ & $\mathbf{2 0 1 0}$ & $\mathbf{2 0 1 4}$ \\
\hline $\begin{array}{l}\text { Patent } \\
\text { Sayılar1 }\end{array}$ & 5 & 219 & 266 & 1,632 & 7,762 & 34,956 & 68,843 & 129,786 \\
\hline
\end{tabular}

Kaynak: Korean Intellectual Property Office

Yukarıda da ifade edilmiş olduğu üzere, G. Kore'nin kendine özgü kalkınma stratejisi çerçevesinde chaebol'lerin ticari faaliyetlerinin desteklenmesi önemli rol oynamıştır. Bununla birlikte bahse konu chaebol'lere sağlanan teşvikin ilk etapta KOBİ (küçük ve orta büyüklükteki işletmeler) özelliğindeki şirketlere sağlanmadığını ifade etmekte yarar bulunmaktadır. Şöyle ki, G. Kore'de KOBİ özelliğindeki şirketlerin sağlam ekonomik ve teknolojik altyapıya sahip olmamaları, uzun vadede G. Kore ekonomisi için bir tehdit olarak algılamış ve bu sebeple bu şirketlere teşvik sağlanmasına ihtiyatlı yaklaşılmıştır (Chung, 1999: 80). Ancak, Asya krizi sonrasında G. Kore, sadık, milliyetçi ve büyük aile şirketlerinin desteklenmesine dayalı olan kalkınma politikasını, KOBİlere de uygulamaya karar vermiştir. Böylelikle, üretimin her aşamasında faaliyette bulunan chaebol'lerin aşırı büyümesi ve dengesiz borçlanmasının arz ettiği potansiyel tehlikenin engellenmesine yönelik önemli bir adım atılmıştır (Krause, 2000: 11). Bu noktada, 1997'de yaşanan Asya krizi sonrasında G. Kore'nin, teşvik politikaları kapsamında kullandırılan kredilerden KOBİlerin de yararlanması ve bahse konu firmalarla işbirliği sağlanması yönünde politika değişikliğine gitmek suretiyle; bahse konu krizi fırsata çevirdiğini de ifade etmek yerinde olacaktır (Mo ve Moon; 2003). Öyle ki G. Kore, sanayileşme politikaları kapsamında, uluslararası pazarda yeni teknolojilerle rekabet gücünü artırabilmek amacıyla teknoloji ağırlıklı çalışan firmalara AR-GE harcamalarını teşvik etme yolunda önemli adımlar atmıştır. Bu sayede G. Kore GSYİH'sinde AR-GE harcamaları için ayırdığı oranın sürekli artış göstererek OECD ortalamasının üstüne çıkmış olması, uygulanan politikanın bir göstergesidir. AR-GE harcamalarına ayrılan bütçenin artmasına paralel olarak, büyük aile şirketleri ve KOBİlerdeki araştırma merkezlerinin sayısı da yıllara göre artış göstermiştir (Tablo 9). Yukarıda da ifade edildiği üzere Dünya Fikri Mülkiyet Örgütü tarafından 2018 yılında yayınlanan küresel inovasyon endeksine göre G. Kore, GSYİH'den AR-GE yatırımlarına ayırdığı pay itibariyle yüzde 4,2'lik oranla dünyada ikinci sırada bulunmaktadır.

Tablo 9: Büyük Aile Şirketleri ve KOBİ'lerdeki Ar-Ge Merkezleri

\begin{tabular}{|l|c|c|c|c|c|c|c|c|c|}
\hline Yil & $\mathbf{2 0 0 3}$ & $\mathbf{2 0 0 4}$ & $\mathbf{2 0 0 5}$ & $\mathbf{2 0 0 6}$ & $\mathbf{2 0 0 7}$ & $\mathbf{2 0 0 8}$ & $\mathbf{2 0 0 9}$ & $\mathbf{2 0 1 0}$ & $\mathbf{2 0 1 1}$ \\
\hline $\begin{array}{l}\text { Büyük Aile } \\
\text { Şirketleri }\end{array}$ & $\mathbf{1}, 084$ & $\mathbf{1}, 083$ & $\mathbf{1 , 1 2 3}$ & $\mathbf{1 , 1 2 5}$ & $\mathbf{1 , 1 4 3}$ & $\mathbf{1 , 1 6 8}$ & $\mathbf{1 , 1 6 1}$ & $\mathbf{1 , 1 6 2}$ & 1,179 \\
\hline KOBİ & 8,724 & 9,186 & 10,685 & 12,198 & 13,831 & 15,551 & 17,614 & 20,624 & 21,880 \\
\hline Toplam & 9,808 & 10,269 & 11,808 & 13,323 & 14,974 & 16,719 & 18,775 & 21,786 & 23,059 \\
\hline
\end{tabular}

Kaynak: Korea Industrial Technology Association, 2011

Tablo 10'da AR-GE merkezleri ve bu merkezlerin sektör bazında dağılımı sunulmaktadır. Söz konusu tablonun incelenmesinden elektronik/elektrik ve makine sektöründeki AR-GE merkezlerinin sayısı dikkat çekmektedir.

\footnotetext{
${ }^{7}$ Kaynak: Kore Patent Kurumu (Korean Intellectual Property Office, KIPO) Ayrıntılı bilgi için bakınız: http://www.kipo.go.kr/upload/en/download/Registrations.xls (04.07.2018)

8 En güncel veri 2011 yllına aittir.
} 
B. Erkök 11/3 (2019) 1401-1416

Tablo 10: Ar-Ge Merkezleri

\begin{tabular}{|l|c|c|c|}
\hline Sektör & KOBí & Büyük Aile Şirketleri & Toplam \\
\hline Elektronik/Elektrik & 9,696 & 385 & 10,081 \\
\hline Makina & 4,296 & 276 & 4,572 \\
\hline Kimya Sanayii & 3,011 & 252 & 3,263 \\
\hline İnşaat ve Mühendislik & 1,312 & 107 & 1,419 \\
\hline Gida İşleme & 468 & 55 & 523 \\
\hline Tekstil & 355 & 21 & 326 \\
\hline Diğer & 2,742 & 83 & 2,825 \\
\hline Toplam Ar-Ge Merkezi & 21,880 & 1,179 & 23,059 \\
\hline
\end{tabular}

Kaynak: Korea Industrial Technology Association, 2011

G. Kore'nin kalkınma politikalarının başında devlet tarafından ağır sanayi yatırımlarının özendirilmesi, fikri mülkiyet haklarının desteklenmesi, ucuz maliyetli kredilerin odak sektörlere yönlendirilmesi gelmektedir. Aynı zamanda, seçilen odak sektörlere yönelik AR-GE yatırımlarının doğrudan devlet eliyle finanse edilmesi AR-GE yatırımlarının artmasının teşvik edilmesinde önemli rol oynamıştır. Zira teknolojik gelişmelere ayak uyduramayan firmalar üretim süreçlerinde ithalata bağımlılıktan kurtulamamakta; bu durum da dünyada rekabetçi konuma ulaşılmasını engellemektedir. Böylece üretim süreçlerindeki dışa bağımlılık artarak devam etmekte; bu durum bir kısır döngü halini almaktadır. Bu noktada, G. Kore ekonomisinin, AR-GE harcamalarını etkin olarak odak sektörlerde faaliyet gösteren şirketlere yönlendirmek suretiyle bugünkü seviyesine ulaştığını ifade etmek yerinde olacaktır. G. Kore, ekonomisinde kayda değer bir büyüme gerçekleştirmenin yanı sıra, teknolojik açıdan da önemli bir gelişim kaydetmiştir. Bu sayede G. Kore, üretim ve ihracatta yüksek katma değer getiren ileri teknolojili ürünlere doğru hızlı geçiş sağlamıştır.

\section{Sonuç ve Tartışma}

Genel olarak iktisat teorileri dış ticareti, büyüme ve kalkınma ekseninde değerlendirmektedir. Öyle ki dış ticaret, ortaya koyduğu kazanımlar nedeniyle büyüme sürecini ve refah artışını; dolayısıyla kalkınmayı olumlu etkilemektedir. İhracata dayalı sanayileşme modeli, liberalleşmeyi öngören; piyasa ilişkilerinin yarattığı kapasite kullanımı, teknolojik yenilik, karşılaştırmalı üstünlükler gibi olumlu dinamik etkileri ön plana çıkaran bir yaklaşımdır. Model, ülkenin sahip olduğu potansiyeller göz önüne alınarak, görece rekabet gücüne sahip olunan sektörlerde üretimin teşvik edilmesi prensibine dayanmaktadır. Özellikle modeli uygulayan Doğu Asya ülkelerinde yaşanan yüksek büyüme oranları göze çarpmaktadır. Bahse konu ülkelerden özellikle G. Kore, insan gücüne ve inovasyona yatırım yapmak suretiyle küresel değer zincirinde zaman içinde yüksek seviyelerde konumlanmıştır. Bu çalışmada, G. Kore'de uygulanılan politikalar incelenmektedir. Zira G. Kore'nin seçilmiş (odak) sektörlere yönelik olarak uyguladığı politikaların incelenmesi, bu sektörlerin küresel değer zincirlerinden edindikleri pay ve bu deneyiminden yol gösterici derslerin çıkarılması, Türkiye'nin uzun dönem istikrarlı büyümeye ulaşmasına katkı sağlayacak nitelikte önemli bir örnektir.

Türkiye'de uygulanan ihracata dayalı sanayileşme modeline yönelik politikalar kapsamında; uluslararası piyasalarda rekabetçi konum elde etmek, yurt içindeki üretimi genişletmek; böylelikle istihdam yaratılması ve ülke ekonomisinin kalkınması hedeflenmiştir. Söz konusu serbestleşme politikaları sonucunda, günümüz itibariyle Türkiye ekonomisi, hedeflenen seviyelerde büyüme ve istihdam yaratamamış; sürekli dış ticaret ve ödemeler dengesi açıkları veren bir konuma gelmiştir. Öyle ki Türkiye'nin 2015, 2016 ve 2017 yıllarındaki dış ticaret açığı sırasıyla, 63 milyar dolar, 56 milyar dolar ve 77 milyar dolar seviyesinde gerçekleşmiş; yine söz konusu dönemde Türkiye'nin ödemeler dengesi sırasıly 32 milyar dolar, 33 milyar dolar ve 47 milyar dolar seviyesinde açık vermiştir. Bu bağlamda, bu çalışmada, Türkiye'ye örnek teşkil etmesi açısından G. Kore'de uygulanılan ekonomi politikaları incelenmiştir.

G. Kore 1948 yılında Japonya'dan bağımsızlığını ilan ettiği dönemde dünyanın en fakir ülkelerinden biri konumunda bulunmaktadır. O dönemde ağırlıklı olarak tarım ülkesi olan G. Kore'nin, bugün ulaşmış 
olduğu başarıyı, Konfüçyus öğretisi başta olmak üzere, Park Chung Hee yönetimine borçlu olduğunu ifade etmek yerinde olacaktır. G. Kore'nin bu dönemde ortaya koymuş olduğu ekonomik gelişme, Park yönetiminin uyguladığı ekonomi politikalarıyla bağlantılıdır. Park 1962 yılında ekonomik büyümeyi yönlendirmek için teknokratlar tarafından görevlendirilen bir Ekonomik Planlama Kurulu oluşturmuş ve beş yıllık kalkınma planları ile ekonomik büyümeyi hedeflemiştir. Sanayileşmede sektöre ilişkin "seçiciliği" ana ilke olarak benimsemiş; tüm sanayiden ziyade, gelişme ve rekabet etme potansiyeline sahip olan odak sektörlerde üretimin desteklenmesini amaçlamıştır. G. Kore, yurt içindeki sanayilere dünya pazarını hedef göstermek suretiyle, imalat sanayisinin kompozisyonunu önemli ölçüde değiştirmiş; üretim ve ihracatta yüksek katma değer getiren ileri teknolojili ürünlere doğru hızlı geçiş sağlamıştır. G. Kore günümüzde, ekonomisini taşıdığı noktaya, insan gücüne ve eğitime yatırım yapmak suretiyle ulaşmış ve bu sayede, kayda değer bir büyümenin yanı sıra, teknolojik açıdan da önemli bir gelişim kaydetmiştir.

G. Kore, kalkınma hamlesine, ülke içinde faaliyet gösterdiği alanda en başarılı olan yerli girişimcileri seçerek ve söz konusu girişimcileri destekleyerek başlamıştır. G. Kore, çoğunlukla aile şirketi olan milliyetçi ve sadık söz konusu girişimci şirketlere çeşitli teşvikler sağlamak suretiyle, bu şirketlerin inovasyon ruhundan faydalanmayı tercih etmiştir. Bu girişimler Korece "chae" (zenginlik) ve "bol" (grup/ takım) kelimelerinden oluşan "chaebol" olarak adlandırılmaktadır. Hyundai, LG ve Samsung, chaebol'lerin en temel örneklerindendir. Bu sayede söz konusu chaebol'ler zamanla emek yoğun üretim yapan basit işletmelerden, teknolojiyi içselleştiren dünya çapında büyük markalar yaratan şirketler halini almıştır.

G. Kore'nin ekonomik kalkınmasının temel ilkelerinden birini, devletin, bireylerin teknik beceriler edinmesine ve bu doğrultuda ters mühendislikle yeni teknolojiler üretmesine yönelik attığı adım oluşturmaktadır. G. Kore'de, planlı dönem içinde, yaratıcılığın, araştırmanın ve inovasyonun gelişmesini teşvik etmek amacıyla, Kore Bilim ve Teknoloji Enstitüsü gibi birçok enstitü kurulmuştur. G. Kore, taklitçilikten inovasyona doğru uzanan AR-GE yatırımları sayesinde, kayda değer bir büyümenin yanı sıra, teknolojik açıdan da önemli bir gelişim sağlamıştır. Bugün gelinen noktada, Dünya Fikri Mülkiyet Örgütü (WIPO) tarafından 2018 yılında yayınlanan küresel inovasyon endeksine göre G. Kore, GSYİH'den AR-GE yatırımlarına ayırdığı pay itibariyle yüzde $4,2^{\prime}$ lik oranla dünyada ikinci sırada bulunmaktadır. Bu sayede G. Kore ihracatının yüzde 25'ini ileri teknoloji ürünleri oluşturmaktadır.

Bu başarıların temelinde, özgün bir kalkınma modeli ortaya koymaları ve eğitime yapılan yatırımlar önemli rol oynamaktadır. G. Kore, odak sektörlere ilişkin sanayi yatırımlarına yönelik sermaye birikimini, DYY kanalından ziyade, yurt dışından borçlanarak sağlamayı tercih etmiştir. Öyle ki yurt dışından sağladığı uzun vadeli fonlar ile yurt içindeki girişimcileri teşvikli kredilerle desteklemiş ve bu sayede DYY'ye bağlı kalmaksızın özgün bir kalkınma modeli ortaya koymuştur.

Türkiye'nin de G. Kore gibi, ülke içinde faaliyet gösterdiği alanda en başarılı olan yerli girişimcileri seçmesi ve söz konusu girişimcileri çeşitli teşvik politikalarıyla desteklemesi gerekmektedir. G. Kore gibi, milliyetçi ve sadık söz konusu girişimci şirketlere inovasyon, AR-GE, düşük maliyetli kredi, finansman kolaylıkları, hibe kredi, vergi indirimi, istihdam, yatırım teşviki gibi çeşitli destekler sağlaması gerekmektedir.

Türkiye'nin de G. Kore gibi, sanayileşmede sektöre ilişkin seçiciliği ana ilke olarak benimsemesi gerekmektedir. Şöyle ki tüm sanayilerden ziyade, gelişme ve rekabet etme potansiyeline ve karşılaştırmalı üstünlüğe sahip olan odak sektörler belirlemek suretiyle; bahse konu sektörlerde üretimin desteklenmesine yönelik politikalar izlemesi gerekmektedir. Ekonominin zayıf ve üstün yönleri bağlamında analiz edilmesi, teşvik politikasının, bu doğrultuda planlanması; teşvikin odak sektörlerde faaliyet gösteren şirketler tarafından kullandırılmasının sağlanması gerekmektedir. Tıpkı G. Kore gibi, desteklenen sektörlerdeki üretimin ve ülke ekonomisine katkısının ölçülmesi ve izlenmesi gerekmektedir. Benzer şekilde, seçilen odak sektörlere yönelik sağlanan teşvikin, gerek üretim için kullanılıp kullanılmadığı gerekse ekonomik gelişime sağladığı katkı bağlamında izlenmesi gerekmektedir.

Şöyle ki teşvik sağlanacak sektörlerin ekonomik planlama esnasında analiz edilmesi büyük önem arz etmektedir. Bu noktada, ekonomik büyümeye ve istihdama katkısı doğru analiz edilmemiş bir sektöre sağlanan teşvikin, ülke ekonomisinin büyümesini ve istihdam artışını sağlamayacağının altını çizmekte yarar bulunmaktadır. Ayrıca teşvik sağlanan sektörün ithal girdiye bağımlı bir sektör olması durumunda, 
yaratılan katma değerin yurt içinde kalmayacağının; böylelikle teşvik ile hedeflenen üretim artışının, ekonomik büyüme ve istihdamın gerçekleşmeyeceğinin dikkate alınması gerekmektedir. Dolayısıyla teşvik sağlanan sektörün üretim aşamasında ihtiyaç duyduğu girdileri yurt içinde tedarik edip etmediği hususunun teşvik planlama aşamasında bilinmesi büyük önem arz etmektedir.

Türkiye'nin de G. Kore gibi sermaye birikimine yönelik kaynağı, DYY'den ziyade, yurt dışından uzun vadeli fon sağlamak suretiyle yaratması; yurt içindeki girişimcilere aktarması, böylelikle yurt içindeki girişimcileri desteklemesi gerekmektedir. Türkiye de tıpkı G. Kore gibi, teknoloji transferini yabancı yatırımcılar kanalıyla sağlamaktan ziyade, yurt içinde tesis etmeye yönelik milliyetçi politikalar izlemelidir. Bir başka ifadeyle, Türkiye de G. Kore gibi, ekonomik kalkınma için DYY'leri ülkeye çekmeye yönelik teşvik politikalarını hızlandırmaktan ziyade, yurt içindeki yerli girişimcileri desteklemek suretiyle yatırım, inovasyon ve nihayet sermaye birikimini özendiren politikalar uygulamalıdır. Türkiye'nin de G. Kore gibi yaratıcılığın, araştırmanın ve inovasyonun gelişmesini teşvik etmesi, insan gücüne ve eğitime yatırım yapması; bu sayede, teknoloji geliştirebilen; yenilikler üretebilen, Samsung gibi dünya markası yaratabilen bir ülke konumuna ulaşması gerekmektedir. G. Kore'de olduğu gibi devletin, bireylerin teknik beceriler edinmesine ve bu doğrultuda taklit ve ters mühendislikle yeni teknolojiler üretmesini özendirmeye yönelik politikalar uygulaması gerekmektedir. Ekonomik kalkınma için Türkiye'nin de G. Kore gibi beşeri sermayeye, AR-GE ve inovasyona yatırım yapması; AR-GE ve inovasyon geliştiren şirketlere teşvik sağlaması gerekmektedir. Türkiye'de de politika yapıcılar tarafından AR-GE ve inovasyon geliştiren şirketlere sağlanan teşvikin AR-GE ve inovasyon için kullanılıp kullanılmadığının izlenmesi gerekmektedir.

Sonuç itibariyle karşılaştırmalı üstünlüğe sahip olan, ithal girdiye bağımlı olmayan, ödemeler dengesini döviz kazandırıcı faaliyetlerle destekleyen ve katma değeri görece yüksek olan hizmet sektörünün (örneğin turizm, müteahhitlik, eğitim hizmetleri gibi) desteklenmesi önerilmektedir. Türkiye'nin ekonomik ve siyasi koşulları dikkate alındığında, görece gelişme potansiyelini haiz söz konusu sektöre yönelik düşük maliyetli kredi, finansman kolaylıkları, hibe kredi, vergi indirimi, istihdam, yatırım teşviki gibi çeşitli destekler sağlanması, gerek sermaye birikimi gerekse ekonomik kalkınma açısından büyük önem arz etmektedir. Söz konusu sektöre yönelik devlet desteği, sektörün gelişimini ve böylelikle Türkiye ekonomisinin büyümesini, kalkınmasını ve istihdam artışını beraberinde getirecektir. Böylece Türkiye de G. Kore gibi karşılaştırmalı üstünlüğe sahip olduğu sektörleri desteklemek suretiyle Hyundai, LG ve Samsung gibi chaebol'ler yaratabilen dünyadaki en büyük ülke ekonomileri arasında konumlanabilecektir.

\section{Kaynakça}

Adelman, I., (1984). “Beyond Export-Led Growth”, World Development, Vol: 12, No. 9, 937-949.

Arslanhan, S., Kurtsal, Y., (2010). “Güney Kore İnovasyondaki Başarısını Nelere Borçlu? Türkiye İçin Çıkarımlar", TEPAV Politika Notu. Ankara: TEPAV.

Balassa, B., (1978). "Exports And Economic Growth: Further Evidence", Journal Of Development Economics, Vol: 5, No. 2, 181-189.

Chang, Y., Seok, H. H.; Baker, D. (2008). Korea Confronts Globalization. Routledge.

Chung, S., (1999). "Korean Innovation Policies for Small and Medium Sized Enterprises", Science and Public Policy, Vol: 26, No. 2, 70-82.

Chung, S., (2011). "Innovation, Competitiveness and Growth: Korean Experiences", In Annual World Bank Conference On Development Economics. Washington DC: The World Bank.

Coe, D. T., \& Kim, S. J. (Eds.). (2002). "Korean crisis and recovery", Korea Institute for International Economic Policy, International Monetary Fund.

Cyhn, J.W., (2002). Technology Transfer and International Production: The Development of the Electronics Industry in Korea, North Hampton.

Ekanayake, E. M., (1999). “Exports and economic growth in Asian developing countries: Cointegration and error-correction models", Journal of Economic Development. Vol: 26, No. 2, 43-56. 


\section{B. Erkök 11/3 (2019) 1401-1416}

Eun, J. C., (2019). Korea Trade Insurance Corporation, Head of International Relations. Kişisel görüşme. 15.04.2019

Hirschman, A. O., (1958). The Strategy of Economic Development, New Haven: Yale University Press.

Han, E.; Kaya, A. A., (2012). Kalkınma ekonomisi: teori ve politika, Nobel Akademik Yayıncllık, İstanbul.

Kazgan, G., (1985). Ekonomide Dışa Açık Büyüme, Altın Kitaplar Yayınevi, İstanbul.

Kim, K. J., (2006). The Development of Modern South Korea: state formation, capitalist development and national identity, Routledge, New York.

Kim, L. ve Rahlman, C.J., (1999). Technology Policy for Industrialization, in (edt), Kim, L., Learning and innovation in Economic Development, Edward Elgar Publishing, Northhamten.

Korea Customs Service, (2018). http://www.customs.go.kr (04.10.2018)

Krause, L.B., (2000). "The Aftermath of the Asian Financial Crisis for South Korea", The Journal of the Korean Economy, Vol: 1, No.1, 31-21.

The Korea International Trade Association (KITA), (2018). http://www.kita.org/ (16.05.2018)

Krueger, A. O., (1974). "The political economy of the rent-seeking society", The American economic review, Vol: 64, No. 3, 291-303.

Lee, S. C., (2006). Industrial Policy in the Park Chong Hee Era. (Edt: Yi, P. C.), Developmental Dictatorship and the Park Chung-Hee Era: The Shaping of Modernity in the Republic of Korea, Homa \& Sekey Books, New Jersey.

Linnemann H., Van Dijck, P., Verbruggen, H., (1988). Export-Oriented Industrialization in Developing Countries, Singapore University Press, Singapore

Mo, J., Moon C. I., (2003). Business Government Relations under Kim Dae Jung. Economic Crisis and Corporate Restructuring in Korea: Reforming the Chaebol, Cambridge University Press, Cambridge.

Michaely, M., (1977). "Exports and growth: an empirical investigation", Journal of Development Economics, Vol: 4, No. 1, 49-53.

Rasmussen, P. N., (1957). Studies in Intersectoral Relations, Amsterdam.

Ricardo, D., (1817). On The Principles of Political Economy and Taxation, Pelican Books.

Schumpeter, J., (1942). "Creative destruction”, Capitalism, socialism and democracy, 82-5.

Seth, M. J., (2017). South Korea's Economic Development, 1948-1996 https://oxfordre.com/asianhistory/view/10.1093/acrefore/9780190277727.001.0001/acrefore9780190277727-e-271 (12.03.2018)

Sönmez, S., (2011a). "Sermaye Birikimi Rejimi ve İhracata Yönelik Sanayileşme (I)", http://www.inovasyon.org/pdf/Sinan.S\%C3\%B6nmez.2011.B\%C3\%B61\%C3\%BCm.I.pdf (19.07.2017)

Sönmez, S., (2011b). "Sermaye Birikimi Rejimi ve İhracata Yönelik Sanayileşme (II)", http://www.inovasyon.org/pdf/Sinan.S\%C3\%B6nmez.2011.B\%C3\%B61\%C3\%BCm.II.pdf. (16.08.2017)

OECD, (2009). Reviews of Innovation Policy, Korea; http://www.oecd.org/sti/inno/oecdreviewsofinnovationpolicykorea.htm (22.08.2018)

OECD, (2012). Innovation for Development, https://www.oecd.org/sti/inno/50586251.pdf (16.04.2018)

OECD, (2014). Economic Surveys Koreahttps://www.oecd.org/eco/surveys/Overview_Korea_2014.pdf (21.06.2018)

Oğuztürk, B. S., Özbay, F., \& Pehlivan, C., (2017). Güney Kore'nin Büyüme Sürecinde İnovasyonun Rolü: Ekonometrik Bir Analiz 1984-2015. Suleyman Demirel University Journal of Faculty of Economics \& Administrative Sciences, 22(4). 
B. Erkök 11/3 (2019) 1401-1416

Yeldan, E., (1989). "Structural adjustment and Trade in Turkey: Investigating the alternatives beyond exportled growth", Journal of Policy Modeling, Vol: 11, No. 2, 273-296.

WIPO, (2018). Global Innovation Index 2018

https://www.wipo.int/edocs/pubdocs/en/wipo_pub_gii_2018.pdf

World Bank, (2019). https://data.worldbank.org/indicator/ny.gdp.mktp.cd?most recent value desc=false (12.01.2019)

UNIDO, (2002). Innovative Technology Transfer Framework Linked to Trade for UNIDO, Action, Bennett, T. (edit.), Vienna: UNIDO

https://www.researchgate.net/publication/264310581_Innovative_Technology_Transfer_Framework_Linked _to_Trade_for_UNIDO_Action (11.05.2018) 